\title{
Securitization of migration and the far right: the case of Greek security professionals
}

\author{
Gabriella Lazaridis* and Dimitris Skleparis**
}

\begin{abstract}
Since the events of $9 / 11$, security concerns have gained unprecedented dominance on western governments' national and international political agendas; Greece has been no exception. The success or failure of a far right party, like Golden Dawn, depends on the effectiveness of the government to regulate immigration and to develop policies aimed at combating the racism which pervades the political culture of society at this particular juncture, when the country is experiencing severe crisis. The aim is to provide an account of the rationale of the securitization of migration from the perspective of Greek security professionals. We argue that the extreme securitizing perceptions of security professionals have been exploited and assisted by far-right extremist groups, which instilled racial violence, hate speech/crime into society, resulting in patterned, unreflective, and routinized security practices and discourses which are more in line with the beliefs and values advocated by the extreme right.
\end{abstract}

\section{INTRODUCTION}

The "securitization" of migration in Greece started in the early 1990s (Karyotis, 2012). The economic and political changes that took place in East Central Europe and the resulting mass influx of migrants into Greece led to repeated restrictive actions, ranging from intensifying border controls to sweeping operations concluding in massive deportations and xenophobic reactions against the "other" (see Lazaridis and Wickens, 1999). The rhetoric for the adoption of intense securitization policies and measures to control cross-border movements intensified with the current economic crisis and the resulting social, economic and other conditions of insecurity for citizens which provided a fertile ground for far right groups in Europe, and in Greece particularly, to use migration as a core target of their anti-"other" politics and actions.

The concentration of immigrants in a few large cities, particularly in the greater Athens area, heightened tensions that had existed since the early 1990s when Greece became an immigration host, and highlighted the shortcomings of immigration policies and the lack of integration policies. Immigration has since become a vote winner in Greece. The success or failure of a far right party, like Golden Dawn (GD), depends inter alia on the effectiveness of the government to regulate immigration, and develop policies aiming at combating the level of racism which pervades the

\footnotetext{
* University of Leicester

** ELIAMEP, Athens
} 
political culture of Greek society at this particular juncture where the country experiences an economic and socio-political crisis.

The aim of this article is to provide an account of the rationale of the securitization of migration in Greece, from the perspective of Greek security professionals, ${ }^{1}$ and to provide an insight on how this rationale was hijacked and reproduced by the far right. The article is divided into two parts. The first part looks at Greek security professionals' intensified practices and the logics of securitizing migration; the second part looks at the rise of the far-right in Greece and the ways in which they used the securitization of migration as a vehicle for justifying their anti-"other" hate speech and crimes. The argument put forward is that these practices and logics of Greek security professionals have been exploited/hijacked by far-right extremist groups, which have instilled racial violence, hate speech and crime into Greek society and subsequently subverted the country's national security, the thing they were aiming to protect in the first place.

The article draws on face-to-face interviews: 10 with GD activists, 15 with pro-migrant civil and state organizations and victims of hate speech and crime and 19 with Greek security professionals from the Hellenic Police and Coast Guard, allocated by the Ministry of Public Order and Citizen Protection after a formal request was submitted. The interviews were conducted in Athens, Orestiada, Alexandroupoli and Lesvos in 2012-13. Access to additional interviewees was gained through already established contacts, taking into account the requirement of specialization in migration issues. Our sample is comprised of male security professionals. ${ }^{2}$ Six of them were high rank officers, 46-60 years old, and thirteen were low rank officers, 30-45 years old.

Furthermore, 12 Masters dissertations on migration issues prepared by Greek elite ${ }^{3}$ security professionals during their study at the School of National Security and the Hellenic National Defence College were analysed. Access to these dissertations was gained after formal applications requesting access were submitted to the aforementioned institutions. Both institutions provide education on a postgraduate level to senior members of the Hellenic Police, Armed Forces, Coast Guard, Fire Brigade, and civil servants of the broader public sector responsible for state security issues. What renders these dissertations so important is the fact that they are produced by individuals who will most probably occupy the highest rank positions within the field of security professionals.

\section{SECURITIZATION OF MIGRATION: THEORIES OF EXCEPTION AND ROUTINE}

This article argues that GD took advantage of pre-existing securitization processes (i.e. securitization discourses and practices) regarding immigration, and by exploiting them in a period when Greece was economically unstable, was able to attract voters. In its current configuration, the literature on securitization - the process of integrating an issue into a security framework that emphasizes policing and defence - relies mainly on two logics. According to Bourbeau (2014: 187-88), "in its current configuration, the literature on securitization - the process of integrating an issue into a security framework that emphasizes policing and defence - relies mainly on two logics." One is the logic of exception, which postulates that security is a process designed to combat existential threats via exceptional measures. The current benchmark in securitization research, the analytical framework proposed by the Copenhagen School $(\mathrm{CoS})$, relies on the logic of exception (Wæver, 1995; Buzan, Wæver and de Wilde, 1998). The other is the logic of routine (Bigo, 2002; Balzacq, 2011; Huysmans, 2006) which views security "as a collection of routinized and patterned practices, typically carried out by bureaucrats and security professionals, in which technology comes to hold a prominent place" (Bourbeau, 2014: 188).

As Bourbeau (2014: 193) argues, "the securitization process is first and foremost about a performance - a process of doing something - and refers to decisions that are socio-historically informed", characterized by recurrence and reproduction. Yet the securitization process 
is also about speech acts - the production of discourses - whose force lies in their repetition, transformation and reactivation (Ibrahim, 2005). The present economic crisis being a critical juncture in its manifestation, together with the $9 / 11$ attacks, legitimized exceptional policies and practices in the face of an existential security threat.

In the Greek case, however, we also have the security professionals who carry out a series of routinized and patterned practices or enter the profession with social capital (strong bonds amongst their peers) and power to legitimize their securitizing moves and behaviours. As Bigo (2001) argues, securitization is largely defined by mundane bureaucratic decisions and practices that create a sense of insecurity and unease. Security is "an attempt at insecuritization of daily life by the security professionals and an increase in the strengths of police potential for action" (Bigo, 2001:111). In the context of the securitization of migration, security is a "transversal political technology, used as a mode of governmentality by diverse institutions to play with the unease, or to encourage it if it does not yet exist, so as to affirm their role as providers of protection and security" (Bigo, 2002:65) and generating a constant sense of insecurity, fear, and danger amongst segments of the population (Balzacq, 2011; Huysmans, 2011; McDonald, 2008).

Fear and unease constitute the basis of (in)securitization. They derive from security professionals' inability to know a person's past and present: "since you don't know his [i.e. the undocumented migrant's] personal details, he can be anything!" (Interviewee A); "we don't know what these people are. We don't know if they are dangerous. We don't know their past!" (Interviewee B). Indeed, "[i]n the migration-security discourse, a continuum of risk identities is brought forward, identities all warranting migration control" (Sorensen, 2012:71). This inability to know a person's identity carries with it the powerlessness to predict future behaviour, which informs the logic of worst-case scenarios that is embedded in governmentality of fear and unease (Bigo, 2008:33). In the Greek case, this logic has been further exacerbated by the lack of reliable data and statistics on migrants, which has created the tendency among the government, political parties and security professionals to scapegoat, particularly Albanian and Eastern European, migrants (see Baldwin-Edwards and Fakiolas, 1998). Contemporary governmentality of fear and unease despises whatever cannot be calculated and predicted. The anxiety about "potentialities" and "likelihoods" creates the urge to tame the uncertain at all costs and by all means, which relegates the "Other" to "the category of cultural and even racial infrahumanity"4 (Aradau and Van Munster, 2009:693). This opens the door to "the harshest, most exploitive, and cruellest treatment that human beings are capable of inflicting on one another" (Massey, 2009:14).

However, an exclusive focus on the logic of routine in securitization processes does not allow room to account for change, critical junctures, or the impacts of "window of opportunities" on contemporary security affairs (Bourbeau, 2014). Indeed, the logic of routine has not managed to provide an understanding of key moments of change in securitization processes, where actors step out of adopted boundaries and transcend the field of action in which they are normally engaged (ibid). By drawing on both the routine and exception approaches to securitization this paper highlights how GD took advantage of the securitization of migration and the present crisis for organizing consent around issues of migration, and thus creating hegemony by mobilizing racist arguments of (natural or cultural) difference, inequality and, hence, exclusion. This struggle for consent based on common sense evokes images of a natural binary constellation between "us" and the "others", partly referring to an existing discourse of difference in Greece (see Lazaridis and Wickens, 1999), and forges these narratives in a common sense perspective of difference and inequality, of belonging and non-belonging.

\section{THE "MIGRATION-SECURITY NEXUS" IN GREECE}

The framing of migration in security terms has been long accepted by the Greek society, before the emergence of GD as the third most popular party. The debt crisis that started to unfold in 2010 further exacerbated this and changed the dynamic between state, citizens and migrants by breeding 
migrant mobilizations, intolerance and reactivating nationalist reflexes, which have facilitated the explicitness of anti-immigration attitudes. The causal mechanism between immigration and unemployment, on the one hand, and extreme right electoral performance, on the other, is the development of anti-immigrant attitudes at the individual level (Aksoy, 2012).

In 2009, 66 per cent of Greeks were admitting that the presence of economic migrants in the country has damaged rather than benefited Greece. In November 2012, few months after the elections, this figure skyrocketed to 78 per cent. Moreover, in June 201160 per cent of Greeks were stating that they are feeling personally annoyed by migrants. ${ }^{5}$ Indeed, in the 2012 elections, despite the greater importance given by voters in general to economic issues, "immigration" ranked just below "unemployment" and "poverty" in their priorities, an assessment which is emphasized by data indicating that Greeks (in 2009) were more concerned about immigration than other Europeans. Additionally, a survey showed that in June 2012 "immigration" ranked as the second most important issue affecting vote, identified as such by 27 per cent respondents. In July 2012, 51 per cent of Greeks were claiming that the unprovoked violence by vigilante groups against random illegal migrants was justified.

Racism and the securitization of migration are everyday behaviours and social practices that have been used for the political project of GD. Moreover, racism and the securitization of migration are embedded in state and institutional structures in Greece.

\section{The effects of the "nexus" on migration policies and migrants in Greece}

The Greek state's response to the sudden influx of migrants from former socialist countries (e.g. Albania, USSR, and Yugoslavia) in the early 1990s was characterized by unpreparedness, inconsistencies and short-termism. Political elites in their public discourses emphasized the need to fortify the borders, protect national identity and curb the development of socio-economic threats that migrants were allegedly deemed responsible for (see Karyotis, 2012). In the absence of a prior migration policy, the legal framework that was enacted in 1991 to deal with those who were referred to as the "Aliens" (Law, 1975/1991) was driven exclusively by security considerations and was designed to discourage flows, by excluding irregular migrants from welfare services including healthcare (except in emergency cases) and education, and criminalizing access to housing and employment (Karyotis, 2012). Additionally, it adopted very narrow definitions on asylum and family reunification, which were in conflict with EU Directives (Mavrodi, 2010). Hence, the massive exodus of Albanians and the female migration from Eastern Europe for sex or domestic work were faced with extensive "sweep" operations, massive deportation campaigns, and political agitation particularly against Albanians (see Lazaridis and Wickens, 1999). Yet, despite the fact that Law $1975 / 1991$ was described as "draconian" due to its disproportionate restrictions, it produced poor results, since a limited number of migrants entered the country by virtue of its provisions, while the vast majority continued to cross the borders and/or remain in Greece illegally (Papageorgiou, 2013).

Within this context, two presidential decrees issued by the government in 1997 regularized 400,000 migrants residing illegally in Greece. Despite its relative success, the scheme failed to fully address the issue of irregular migration, as many eligible migrants failed to register, while irregular bordercrossings by migrants who were ineligible for regularization continued to rise (ibid). This situation led to the adoption of law 2910/2001, a hastily drafted law that was amended seven times during the five years it was in force. 2910/2001 transferred the responsibility for immigration to the Ministry of Interior in an attempt to frame the issue in political, social and economic terms. However, illegal entries and overstays persisted, while excessive conditions hampered legal migration channels (ibid).

A new Law, 3386/2005, was put in place on January 1, 2006 (and amended in January 2007 with Law 3613/2007), bridging slightly the gap between Greek and the EU legislation by introducing some level of liberalization and rationalization, particularly in relation to reunification conditions, residence and work permits procedures, human trafficking and education. However, irregular migrants, who formed the majority in the country, were ineligible for these provisions, which 
rendered them almost meaningless (Gropas and Triandafyllidou, 2005). In the absence of an effective migration policy with a long-term view, the state opted for a series of regularization programmes (adopted in 2005 and a smaller one in 2007), granting amnesty to categories of long-term migrants. As with other aspects of migration legislation, these successive one-off programmes, were not only hampered by bureaucratic insufficiency and complexity but, more importantly, were interpreted as a "pull factor" which encouraged others to seek entry into Fortress Europe.

The effects these policies had on the migrants were detrimental, institutionalizing legal and psychological insecurity and leading to different degrees of exclusion-inclusion for different migrants, which in turn formulate a process of abjectification during which migrants are transformed from legal subjects to repulsive legal abjects (Lazaridis, 2011). Meanwhile, in 2007, a ten-fold increase in the numbers of migrants arriving on the Greek coastline resulted in serious problems of overcrowding at the detention centers in Samos, Chios and Lesvos (IOM, 2008: 40). Indeed, the detention facilities of migrants were described as "grim" and compared with "medieval dungeons" (HLHR, 2009:10).The detrimental impact of securitization for migrants in combination with the ever-growing migration flows led UNHCR to describe the situation for migrants and asylum seekers in Greece as a "humanitarian crisis" (UNHCR, 2010).

Within this context, in August 2012, the Hellenic Police enforced the "Xenios Zeus" operation, a major internal migration control strategy, which attracted heavy criticisms by NGOs, such the Human Rights Watch (see HRW, 2013). According to this report, the "lengthy and intrusive procedure" of "stop and search" identity checks amount to "arbitrary and discriminatory deprivation of liberty" (ibid:2) and are unlawful, as they discriminate people based on their physical characteristics, and ethnic/racial profile (ibid:3,5). Body pat-downs, bag searches, disrespectful treatment, rude, insulting and threatening behaviour, even physical violence were described as routine (ibid:4).

One of the immediate side effects of the "Xenios Zeus" operation was the renewed deterioration of migrants' and asylum seekers' living conditions in detention facilities. According to Pro Asyl (2012:3), overcrowding, poor hygiene, sporadic violence and lack of access to legal aid, information and translators, made the facilities "synonymous with brutality, despair and dehumanization". There was also a notable absence of any provisions for vulnerable populations, such as unaccompanied minors, mentally or physically ill and victims of torture - instead, all types of migrants and asylum seekers were merged into a single policing regime.

The deeply rooted securitization of migration in Greece that traces back to the early 1990s has shaped migration policies that are essentially restrictive and block all legal migration channels, despite spasmodic attempts to move migration outside the security realm. Under this prism, the regularization schemes can be seen as attempts, patterned on the developments in other EU countries, to cover up bureaucratic deficiencies, inconsistencies and short-termism in migration policy. The securitization of migration and the respective policies in Greece, not only have failed to produce substantial results in migration control, but their consequences have been detrimental to migrants' livelihoods, as the European Court of Human Rights ruling decisions against Greece manifest in a number of cases. ${ }^{6}$ Indeed, the only winners in the securitization of migration in Greece have been diachronically the far- and extreme-right parties (Karyotis and Skleparis, 2013).

The examination of Greek security professionals' dissertations and the interviews with them uncovers the basis on which the "migration-security nexus" has been formed in Greece. This basis is fundamentally related to Greek security professionals' definition of the notion of "security", which, in all cases, is identified with national security (Interviewee C) ${ }^{7}$, an understanding that derives from a "Cold War" conception of the notion of security.

Mass migration then, is, first and foremost, a national security issue (Interviewee D), since "[c] ontrol over borders is increasingly seen as one of the last bastions of sovereignty" (Casey, 2010:25). This thinking informs the use of war-like metaphors in relation to migrants. Interviewee E, for instance, argues that Greece became "the target of migrants", while he is also talking about 
"the migrant invasion". Interviewee F refers to "the armies and caravans of miserable migrants" that arrive in Greece. Moreover, it informs the use of disaster-related metaphors; Interviewee D for instance, uses the phrase "whirlwind of illegal migration" to describe the intensity of the phenomenon. Fear and unease constitute the key components of all these metaphors.

\section{The fear of criminality and terrorism}

Underneath the formation of the "migration-security nexus" in Greece lies security professionals' fear that there is a direct link between migration and criminality (Interviewees G, H, I, J, $\mathrm{K}, \mathrm{L}$ ).

More specifically, similarly to GD activists we interviewed, Greek security professionals suggest two explanations for the increase of criminality rates in the country: first, they are attributed to the entry of criminal migrants in the country, either in order to escape from their home countries' authorities (Interviewee M), or because they are part of their home countries' "population dumping" strategies (Interviewee G), or due to the grave economic conditions in which migrants have to live in Greece: "[a]ll these migrants constitute a threat to public order, since they are unemployed. Illegal migration goes hand-in-hand with criminality, especially now that there is unemployment" (Interviewee N). Moreover, "many of the crimes committed by foreigners are characterized by unprecedented impudence, toughness, cynicism, roughness and savagery for Greek standards" (Interviewee G).

"Illegal" migration, apart from the rise of criminality, has been blamed for the emergence of organized crime, "since illegal migrants constitute its recruitment pool. Smuggling of illegal migrants is one of its main activities" (Interviewee O). One of the interviewees argued that the economic benefits that occur for these networks from "illegal" migration are reinvested in other criminal activities, such as human trafficking, drugs, cigarettes and weapons smuggling etc (Interviewee P).

After the 9/11 attacks, migration was also linked to terrorism in many Western countries (Faist, 2004; Diez, 2007). This development instilled a new fear into Greek security professionals and created serious concerns as to the potential repetition of similar attacks on Greek soil. Interviewee $\mathrm{H}$ suggests that the possibility of infiltration of terrorists in Greece through "illegal" migration channels should not be excluded. Thus, in the face of the terrorist threat, it is imperative for Greece to take security measures and strengthen its border controls (Interviewee $\mathrm{O}$ ).

Greek security professionals also expressed their concerns regarding the potential radicalization of the existing migrant population. Interviewee F suggests that "there is a fertile ground for terrorism in Greece, as the large migrant population constitutes the ideal recruitment pool ... due to poverty, the grave conditions they are living in, their illegal status, and their socialization with outlaws." Thus, "part of the Muslim youth, second-generation migrants, can potentially become radicalized and turn against the society in which they were born and raised" (Interviewee E). Moreover, "Albanian expansionism, which claims Greek territories, combined with the large number of Albanians in Greece, as well as the large availability of weapons that were seized during the 1997 civil unrest, can constitute an asymmetric threat" (Interviewee $\mathrm{H}$ ).

\section{The Economic fear}

Another fear harboured by Greek security professionals is that migration harms the national economy. Both Interviewee L and Interviewee J link "illegal" migration with the emergence of a parallel economy and black markets. This eventually leads to a drop in public revenue, as employers hire "illegal" migrants but refrain from paying for their social insurance, which leads to burdening 
the state budget. They thus fail to recognize that the informal economy has been a characteristic of the Greek economy long before the mass influx of migrants which started in the early 1990s.

Yet migration also causes an increase in public spending and puts a burden on the country's welfare services. "Illegal migrants take advantage of the democratic values and humanitarianism of Greece by using the country's social welfare services in a disproportionate way" (Interviewee L). They benefit from the social welfare system but they don't contribute anything to it, which leads to the increase of public spending regarding healthcare, education and national security (Interviewee D). In other words, similar to GD they argue that migrants are threatening the social welfare system with collapse, which results in the increased taxation of Greek citizens.

Finally, another point of similarity between them and the GD is that economic fear is related to the increase of unemployment among the native workforce due to migration. Interviewee $\mathrm{J}$ states that "the native workforce is substituted by the foreign one [...] The labour market shows its preference for foreigners because they work for less and they work more". This substitution occurs more often in professions that require unskilled labour (Interviewee F). In this respect, "some of the lower social classes of the Greek society have been marginalized and have experienced the loss of jobs and labour rights and reduction in salaries" (Interviewee H).

\section{"Us" vs. the "Others": the fear of demographic and cultural erosion}

A number of studies we analysed brought forward Greek security professionals' fear of the demographic and cultural erosion of Greece due to migration. Interviewee D states that the regularization of hundreds of thousands of migrants, combined with their high fertility rates and the existing demographic problem will result in Greeks becoming a minority in their own country. ${ }^{8}$ Interviewee $\mathrm{H}$ maintains that there are regions in Greece where migrants constitute 25 per cent of the population. Interviewee $\mathbf{J}$ expresses his concerns over the safeguarding of Greece's national sovereignty, as the demographic problem will force the Army in the long-term to draft migrants with unprecedented consequences for the national security. Thus, the demographic problem, which is further exacerbated by illegal migration, constitutes a mid-term problem with very serious implications for the national existence of Greece (Interviewee D).

Apart from the danger of demographic erosion, there is also the fear (shared with GD activists) that migration can erode the ethnic, cultural and religious homogeneity of Greece (Interviewee L), that is, "our national identity". Interviewee E suggests that "the mindset and the social structure of the country is distorted as migrants bring with them their customs and opinions on different social issues, such as religion, education, morality and values". Indeed, these fears are existential, threatening Greeks' ontological security, as "the erosion of the ethnological base of our country will bear painful consequences for Hellenism" (Interviewee D), while the worst case scenario is that "[i]n the not so distant future Hellenism will cease to exist" (Interviewee E). Thus, they concur with GD's views that "[o]ur national homogeneity must remain coherent, and we must not allow to lose peacefully, whatever we gained through struggles" (Interviewee E).

Behind the fear of the migrant "Other" lies the uneasy assumption that migrants are unable to integrate into Greek society. Interviewee $\mathrm{E}$ argues that the vast majority of these uninvited migrants are impossible to assimilate into Greek society for ethnic, cultural and religious reasons, as the values of Islam are largely incompatible with those of Western Europe, which leads Muslim migrants to ghettoization. "Democracy and Islam are not compatible with each other", as "the Islamic world demands the adjustment of the laws and liberties of the host state to its own laws and customs" (Interviewee L). Interviewee L suggests that "we are on the verge of seeing a crude and ruthless Islamic imperialism that threatens with extinction the established rights of the peoples of Europe, 
for which, century-long political, social and cultural fights were given". All in all, "Muslims in Europe are behaving as if they are living in a predominantly Muslim society", while "the vast majority of them consider themselves as bearers of a superior civilization" (Interviewee L). This argument brings in mind the famous "Clash of Civilizations" thesis, where Huntington (1996:217) argues that Islam is "a different civilization whose people are convinced of the superiority of their culture and are obsessed with the inferiority of their power". As one of the interviewees put it: "we have nothing in common with the new migrants. We have an utterly different culture" (Interviewee Q). Discourses of exclusion based on racialization contribute to a right-wing racist project of a homogeneous society where the presence of "others" is in itself problematic. Therefore, racialization involves power, as it shifts power to the "we" group and at the same time disempowers the “others" (Terkessidis, 2004: 99).

This unease with Islam and Muslims leads, in some cases, to the perception of migrants as infrahuman. Interviewee E states that "the arriving illegal immigrants are pathetic individuals" that "[...] are nothing more than the contemporary version of the barbaric tribes' invasion of the empires of antiquity and Middle Ages." In this regard, "we must not let the thousands of uncivilized Third Worlders that came to our country illegally take apart our nation state and our ethnic homogeneity" (Interviewee F). Moreover, during an interview one of the police officers kept using degrading terms, such as "stinkers" and "animals", to refer to migrants. This same interviewee also expressed an opinion that captures quite clearly the core of this perception:

what are you going to say to a person who sees a toilet and doesn't know how to use it? It doesn't mean anything to him if you put him in a detention centre that is old or crowded. He used to live in dirt. It means shit to him. However, I've seen fancy migrants; fancy for their own countries' standards though, not for Greek standards. But they are very few (Interviewee N).

Understanding institutional racism gives an indication of why right-wing populist and extremist groups are successful. Racist undisputed discourses and practices build a solid ground for far-right populists to create a "common sense" and a hegemonic discourse based on (natural) inequality and, hence, exclusion, while securitization of migration gives far-right-wing populists like GD the armour to give their hate discourse and actions legitimization. The construction and legitimation of difference and inequality - based on biological or cultural arguments - is central for the securitization of migration and for racist practices. The fact that racism is deeply embedded in the everyday discourses and practices of security professionals and that it has become a form of societal knowledge explains its persistence (Terkessidis 2004: 109).

However, apart from Muslim migrants, another aspect of securitization of migration that paved the way for GD is that Greek political elites are also considered by security professionals as an "Other" that is treated with suspicion, and who is capable of instilling fear and unease. According to this line of thought, "the political, social and spiritual elites of the country seem to have utterly and unquestionably accepted [...] the "multicultural" experiments that pose a direct threat to the ethnic and social coherence, national security, and political and state stability of the country" (Interviewee E). Indeed, "the last 20 years [...] our country's migration policy has been characterized by a weird tolerance towards migration, which constitutes a pull-factor for waves of illegal migrants" (Interviewee D). However, "the pinnacle of the malaise, weakness, and suspicious indifference of our political system [towards migration]" is the new nationality law, which is perceived as constituting a potential national security threat due to the fact that it introduces elements of jus soli to the Greek legislation (Interviewee D). Again, these arguments are in line with the Huntingtonian thesis: "[t]he American multiculturalists wish to create a country of many civilizations, which is to say a country not belonging to any civilization and lacking a cultural core. A multicivilizational United States will not be the United States; it will be the United Nations" (Huntington, 1996:306). 
Finally, members of NGOs, migrant associations, pro-migrants activists and left wing parties are also part of the assemblage of unease and are treated by Greek security professionals as "dangerous Others". More specifically, a Coast Guard officer in Lesvos argued that

[w] respect human rights, but we are not interested in them. In general, we didn't have good relationships [with the NGOs]. They contribute nothing. Only protests and demonstrations (Interviewee $\mathrm{R})$.

Along the same lines, a police officer stated that "I don't like it when [the NGOs] go beyond certain limits" (Interviewee S). Another officer added:

does the wolf love the sheep? Our relationships have been improved, but the wolf never loves the sheep. No matter what, in order to work for an NGO that deals with detained migrants, you have to be a supporter of SYRIZA. And SYRIZA do not like the police ${ }^{9}$ (Interviewee N).

These quotes manifest that security professionals perceive NGOs as politicized actors and bearers of a political agenda that is in direct opposition to a national security agenda. Additionally, they reveal a very specific attitude towards human rights, which classifies them as an issue of secondary importance.

The past 25 years, the gradual "Europeanization" of the Greek field of security professionals and the "harmonization" of the methods of controlling/managing migration have ended up undermining the "security expert status" of Greek security professionals and their monopoly to legitimately identify and deal with threats. In this regard, Frontex security professionals, for instance, appear to promote a much broader European security agenda, the externalization of border controls, intergovernmental/interagency cooperation, and the increased utilization of new technological trends in the control and management of irregular migration. However, all the security professionals interviewed shared the view that under the current regime of migration management "the control and deterrence of illegal migration is futile". Indeed, in contrast to their European counterparts, Greek security professionals insist on traditional military thinking and national interests, and rely on local knowledge, human sources and a national security agenda in order to cope with risk and the logic of worst-case scenario. This "struggle" between Greek security professionals and their European counterparts has pushed the former to adopt even more "extreme"/"radical" securitizing logics and practices in their attempt to safeguard their "security expert status" and their monopoly to legitimately identify and deal with threats (Skleparis, 2015).

Nevertheless, these "extreme"/"radical" securitizing logics and practices of the last decade have not been adopted homogeneously by all Greek security professionals. The security professionals who occupy the most "radical" positions within the Greek field of security professionals are those that have never received any kind of Frontex training and have never been involved in procedures where socialization with Frontex officers is mandatory. In other words, Greek officers that have never attended seminars/workshops/training sessions organized by Frontex tend to enter more often into "struggles", so to speak, with their Frontex colleagues, Greek political elites, and members of NGOs over the "security expert status" and the monopoly to legitimately identify and deal with threats. Moreover, Greek officers deployed in the detention of irregular migrants/asylum seekers, the management of asylum seekers, and the internal control/ management of irregular migrants - or else, in "realms" where Frontex officers have no involvement at all - tend to compete regularly with their Frontex colleagues, politics professionals, and members of NGOs over the monopoly to legitimately identify and deal with threats. In simple terms, Greek security professionals that have been asymmetrically included in the gradually "Europeanized" national field of security professionals and the "harmonized" methods of controlling/managing migration have adopted in recent years more "extreme" securitizing logics and practices in their attempt to safeguard their "security expert status" and their 
monopoly to legitimately identify and deal with threats against their European and better integrated fellow-countrymen security professionals.

\section{POLITICAL CONTEXT WITHIN WHICH SECURITY PROFESSIONALS OPERATE: THE RISE OF THE FAR-RIGHT IN GREECE}

GD was the most spectacular beneficiary of the securitization of immigration debate, rising from 0.29 per cent in 2009 to almost 7 per cent in 2012 and winning respectively 21 and 18 parliamentary seats in the May and June 2012 elections and was reduced by only 1 seat to 17 in the January 2015 elections (see Table 1) despite nine of its MPs being held in jail on charges of extortion and weapons possession. In 2014, the far-right party gained the third highest share of the vote in the European Parliament elections in Greece, translating into three MEPs, percentages which ranked GD as the third political party in electoral support behind New Democracy and SYRIZA.

Several reasons help explain why GD has emerged as a parliamentary political party: (1) the environment of disappointment over the financial crisis; (2) rising poverty and raging unemployment; (3) the continuing disapproval of the traditional ruling parties New Democracy and PASOK, which are considered to be corrupt and culpable for the current financial situation in Greece; and (4) an anti-immigrant, racist campaign which has appealed to a rising post-crisis nationalism and has been fuelled by the failure of the state to deal effectively with the problem of illegal immigration in Greece (Akrivopoulou 2013).

GD has been characterized as a neo-Nazi, fascist, racist and xenophobic political organization, although the party officially rejects these labels and refers to itself as a popular nationalist patriotic party. Its flag closely resembles the Nazi swastika, and many of its leaders proudly unleash the Nazi salute, while they carry out pogrom type attacks on the "other", that is immigrants, homosexuals and political opponents.

Since the onset of the economic crisis and the severe cuts that were launched with the bailout reforms, the party has stepped in with a social programme. GD has formed a non-profit organization, named OAED after the acronym of the "Manpower Employment Organization" which is the official state organization for the unemployed, but in the case of the GD's organization the acro-

TABLE 1

ELECTORAL RESULTS OF GD (1994-2015)

\begin{tabular}{|l|c|}
\hline Electoral Year / Types of Elections & Electoral Results \\
\hline $1994($ E) & 0.11 \\
$1996($ P) & 0.07 \\
$1999($ E) & 0.75 \\
$2002(\mathrm{M})$ & 0.30 \\
$2004(\mathrm{E})$ & 0.17 \\
$2006(\mathrm{M})$ & 1.34 \\
$2009(\mathrm{E})$ & 0.46 \\
$2009(\mathrm{P})$ & 0.29 \\
$2010(\mathrm{M})$ & 5.29 \\
$2012 /$ May(P) & 6.97 \\
$2012 /$ June(P) & 6.92 \\
2014(E) & 9.39 \\
2015/January(P) & 6.28 \\
2015/September(P) & 6.99 \\
\hline
\end{tabular}

Source: Ministry of Internal Affairs, http://www.ypes.gr/el/Elections/ 
nym means "Group for the Unemployed Hard-Hit Greeks". Its goal is to find jobs only for Greeks. A Greek farmer, in collaboration with the local GD Offices in a region two hours distant from Athens, advertised in local newspapers asking for thirty exclusively Greek workers for casual work to collect oranges and tangerines, fifteen of whom might also be employed in his olive trees in the near future. These practices are illegal according both to Greek and EU law.

GD's anti-immigrant rhetoric is summarized in their repeatedly used slogan "every foreign worker is a Greek unemployed". Incidents like one in a strawberry production farm in southern Greece where immigrant workers were shot by their supervisors for demanding to get paid for six months of unpaid work, have undoubtedly been triggered by the virulent GD's anti-immigrant rhetoric. Although in this particular case, GD publicly refused its involvement and condemned the shootings, in an official announcement the party stated that these issues arise because jobs were stolen from Greeks and given to immigrants, and that the only solution to the problem is the immediate expulsion of illegal immigrants living and working in Greece. These racist practices and discourses of GD have been paved by the well-established fear of security professionals that migration harms the national economy.

Under the slogan "Return Greek people's money to the people", GD have organized open food donations in central squares all over Greece. However, in one of the public food donations in Athens, GD MP, Ilias Panagiotaros, refused to give food to an immigrant lady and urged her to go and ask for food from SYRIZA which, according to his opinion, is the protector of immigrants (Koronaiou and Sakellariou, 2013:336). Indeed, SYRIZA, as well as migrant-/refugee-serving NGOs, has been persistently presented by security professionals as part of the assemblage of unease. In order to ensure that food is donated only to Greek citizens (according to GD, people whose both parents are of Greek origin) people queuing for food are required to present their identity cards.

One of the actions GD took after the 2012 elections was to create a blood bank, as a response to chronic blood shortages in Greek hospitals. Announcements and slogans such as "Donate blood Save a Greek soul" were circulated, stating in the text accompanying this announcement that the blood is "only for Greeks". There were reactions by medical doctors who claimed that blood is for everyone and no one can control who gets blood except by clinical criteria (ibid:333-334). Another health initiative of GD has been the formation in December 2012 of "Medicines Avec Frontiers", in opposition to the international organization "Medicines Sans Frontiers". In their inaugural announcement they stated that "the service is only for Greeks". They also stated that "almost three million illegal immigrants are treated by the Greek hospitals for free and this is the basic reason why the health system is in this mess" (ibid). Longstanding securitization practices and discourses of exclusion based on racialization have contributed to the rise and establishment of far-right-wing populism as a political project.

Yet another area of activism in which GD engages is that it ostensibly offers protection for victims of crime, especially when immigrants are allegedly the perpetrators, a service that has been appreciated by citizens and utilized by the police. The party demands allegiance in return for their service. Such frames, portraying immigrants as the "dangerous others", have been used by the GD like lenses to amplify a subset of potentially relevant considerations, like the rise in crime in Greece, and the potential danger the immigrant poses to people's security, while blurring other concerns, like the usefulness of migrants in sectors where labour shortages are being experienced, like for example the caring sector. Following Entman (1993), it promotes a moral evaluation that migrants are bad and we need to protect our people's security, and a treatment recommendation, which is to expel all migrants. Greek society and security professionals have long ago accepted and (re)produced this frame as the predominant one in defining and dealing with migration, which has essentially "securitized" the issue, legitimizing in this way the adoption of urgent responses to block its development, which otherwise might not have been possible (ibid). 
Members of GD have been accused by the other political parties in the Parliament of carrying out acts of violence and hate crimes against immigrants, ethnic and other minorities and political opponents. For example, its supporters - in some instances with the alleged cooperation of the police - stand accused of unleashing a rash of violence since the party rose to national office, including the stabbings and beatings of immigrants, ransacking an immigrant community centre, smashing market stalls and breaking the windows of immigrant-owned shops. Attacks have not stopped at foreigners. Activists see the party's hand behind beatings of gay men. GD has also begun engaging left-wing and anarchist groups in street battles - more evidence, observers say, of a societal breakdown that some fear could slide into a civil war if Greece is forced out of the euro and into an even deeper crisis. Indeed, racism has built a solid ground for GD to create a "common sense" and a hegemonic discourse based on (natural) inequality and, hence, exclusion, while securitization of migration has given GD the armour to give their hate discourse and actions legitimization.

The rise of GD and extremism in Greece can be seen as part of a broader phenomenon of a culture of intolerance, which is maintained and perpetuated through the Greek education system (Halikiopoulou and Vassilopoulou 2013). Strong anti-immigration sentiments and the rise of the far-right reveal a deeply nationalistic society which has been socialized towards violence and defiance from a very young age. Regarding hate speech and incitement to violence, on many occasions the far-right expressed opinions that threaten human rights, declared specific criminal intent, including such that later materialized. Consider for example statements made to journalists during the campaign for the 2010 local election, when a then-candidate for municipal councillor and later a GD MP said that "if GD elects a municipal councillor in Athens, a pogrom will ensue". During an electoral campaign speech on June 2012, the same GD MP informed the public that "if GD enters the Parliament, it will storm hospitals and childcare establishments and start throwing out illegal immigrants and their children, in order to replace them with Greeks." The organization took action soon after, with its members and MPs visiting hospitals in order to terrorize foreign patients and nurses, creating a climate of fear and fostering an atmosphere of discord, animosity and hatred.

Along the same lines, security professionals in Greece have taken an extreme stance towards migrants. Indeed, one of the interviewed police officers in Athens stated that "we must make Greece inhospitable to migrants. I mean that all Greeks must stop our financial relations with them in order to make them understand that there is nothing here. No charity, no philanthropy, no job offers". Moving in the same direction, the Head of the Hellenic Police stated in a meeting with elite Police Officials that "we have to make their [migrants'] lives hard" (DocTV, 2013). The same opinion was expressed by the former Minister of Public Health, Adonis Georgiadis, in a newspaper interview: "we must make their [migrants'] lives difficult in order to make them understand that they are unwanted in the country and leave" (Proto Thema, 2013). In this sense, GD hijacked and reproduced the key frames in the dominant discourse of security professionals and political elites, which predated the rise of GD.

The escalation of violence by GD action squads reached its peak in January 2013 when a 27year-old Pakistani, Sahjat Lukman, was murdered by two GD members. ${ }^{10}$ Even before that, as a leading activist of the "Steki metanaston" (a pro-migrants NGO that participates in the Racist Violence Recording Network together with other parties and human right organizations under the auspices of the UNHCR and assists inter alia victims of racist attacks) stated that racist attacks in the centre of Athens reached a peak immediately after the 2012 national elections, when GD elected members in the parliament. According to the "Steki metanaston", only in the summer of 2012, 460 victims were recorded as being beaten by GD action squads, and went to hospital. As a member of Steki Metanaston told us, "[t]he victims of racist attacks are afraid to go to the police in case they are deported, or ask for protection by judicial authorities. In most of the cases they are illegal immigrants. They just get into the hospital to be treated, and then they leave". 
From the records that the Ombudsman collected for a period of 16 months (from 01/01/12 to 30/ 04/13), from different sources (i.e. complaints to the Ombudsman, media, other organizations registering racist violence etc), there have been 281 cases of attacks identified, connected to "othering" as far as nationality, colour, religion, and sexual orientation is concerned. 253 out of the 281 of these attacks took place in 2012, the national elections year in Greece and the election of GD deputies in the parliament. 71 cases were attributed to GD members and 47 to violence exercised by the police. There were four dead people, and more than 135 cases of physical injuries. The attacks took place mainly in Athens, Crete, and Western Greece. The attackers beat their victims with batons, clubs, brass knuckles, and knives. In some cases they used dogs. The time of the attack would usually be after dark, or very early in the morning. Sahjat Lukman was attacked and killed very early in the morning going by bike to work. The President of the Pakistani community in Athens, Javed Aslam told us that he could account for another four murders of Pakistanis and around 800 violent racist attacks preceding Lukman's, and at least 500 attacks within two months around the 2012 national elections. There are different numbers of racist attacks recorded from organization to organization, making it difficult to decipher exact numbers. All the attacks were mainly against men.

The Ombudsman's office told us that the Greek state remained in a state of apathy, avoiding dealing with the essence of the problem. From 2005 to 2010 the police would not intervene in petty crimes in neighbourhoods. There was a public void, an open space for GD to take over the security of these specific neighbourhoods and in a way substitute the police. However, after the collapse of the Greek economy, and the election of a more conservative government in 2012, the police went to the other extreme. Police officers started collaborating with GD members. There are police stations, we were told, such as the one in Omonoia square or in Agios Pandeleimonas area in the heart of Athens, which literally belong to the GD. According to a lawyer we interviewed, migrants beaten by GD activists are then taken to police stations where they are physically and verbally assaulted by officers. The outcome of disciplinary hearings against policemen engaging in racist behaviour, or acts, is really disappointing. In a total of just 22 such cases, only six were completed, and there has been only one conviction against a policeman to whom a fine was imposed.

\section{CONCLUSION}

In this article, we provided an insight on how institutional racism and securitization of migration get "locked in" and can lead to patterned, unreflective, and routinized security practices and discourses which are more in line with the beliefs and values advocated by a party of the extremeright, rather than a western democracy.

Unease at the border, border protection and the securitization of migration in the case of Greek maritime and land borders are linked with persistent tensions in the relations of Greece with its neighbours, particularly Turkey and Albania. Thus, the securitization of migration in Greece can be traced back to the early 1990s, when the country first became a host of mass migration flows, especially from Albania. Similarly, racism and xenophobia in the country did not emerge after the 9/11 events, nor in tandem with the economic crisis and the rise of GD in 2010; rather they are rooted in the early 1990s (see Eurobarometer, 1997). Indeed, in overall Europe, securitization and antiimmigration attitudes date back to the Europeanization of migration policy in the 1980s (Huysmans 2000).

In the Greek case there were undoubtedly critical junctures, like the onset of the economic crisis, the rise of GD and the securitization process after 9/11, which were key moments of change that provided windows of opportunities for escalating securitization practices under the logic of exception. However, an exclusive focus on critical junctures does not allow space for an account of everyday routine practices and unreflective discourses which emanate from deeply xenophobic and 
racist ideas and beliefs that Greek security professionals harbour. These have provided the fertile ground on which later unreflective decisions were taken unthinkingly and habitually and gave GD an excuse to step outside adopted boundaries. Following Ikenberry (1994) and Mahoney (2001), once the securitized understanding of an issue, in our case immigration, is set in motion, the securitization pathway is difficult to alter.

Successful securitization moves entail the creation of hopes and expectations among the public that the securitized issue can be successfully dealt with by inreased controls. In simple terms, when security professionals and political elites successfully securitized migration in Greece, they also created the hope and expectation that this issue can be and has to be controlled. However, this never happenned. In fact, Greece is currently experiencing one of the largest immigration flows in its modern history. Furthermore, interviewed security professionals expressed the opinion that under the current regime of migration management "the control and deterrence of illegal migration is futile". Yet, the hopes and expectations of the public have to be fulfilled. Within this context, it is actors like GD that step in and "perform" the control of the phenomenon, reaping the gains of the empty promises made by security professionals and political elites. In reality, the public does not expect GD or similar actors to produce substantial results and actually control migration. The public just expects them to stand up to or pretend that they are standing up to the fear and unease that political elites and security professionals have created and failed to alleviate. Hence, GD effortlessly hijacked and reproduced preexisting securitization frames and discourses and reaped electoral gains by employing practices that matched the magnitude of the hopes and expectations falsely cultivated in the public by political elites and security professionals alike throughout these years. In sum, only actors whose practices lie at the fringes of legality can live up to the hopes and expectations that the successful securitization of migration cultivates to the public.

\section{NOTES}

1. The term 'security professionals' is borrowed from Bigo (2002), and includes the police, intelligence services, customs, immigration services, border guards and the military.

2. Women were allowed to join the Hellenic Police in 1983 for the first time. However, a 10 per cent quota was established, which remained in place until 2003. This has led to the overrepresentation of men in the Hellenic Police, which is partly responsible for our gender biased sample. Moreover, women are particularly underrepresented in Police services that deal with migrants, but not in the Asylum Department.

3. The Greek security professionals that prepared the dissertations were either Police Majors or Police Lieutenant Colonels.

4. Cultural/racial inferiority.

5. These figures have been kindly provided by qed, Public Opinion and Market Research Company.

6. Recent cases include $S D$ v Greece (53541/2007, 11 June 2009), Tabesh v Greece (8256/2007, 26 November 2009), AA v Greece (12186/2008, 22 July 2010), RU v Greece (2237/2008, 7 June 2011), Rahimi v Greece (8687/2008, 4 July 2011), Grand Chamber MSS v Belgium and Greece (30696/2009, 21 January 2011).

7. Interviewee $\mathrm{F}$ suggests that national security 'is influenced by and related to the Armed Forces, national economy, public order and security, demographic evolution, religious coherence and the administrative and social organization. The general rule is that whatever harms one aspect of security harms the rest too.

8. According to the World Bank, the fertility rate in Greece in 2012 was 1.3 , well below the EU's average (1.6).

9. Left-wing parties are also perceived as a security threat because they "vigorously support the idea of open borders, and try to politically exploit the stock of illegal migrants in order to create social unrest and intense confrontation with the state" (Interviewee D)

10. Since the murder of the anti-fascist musician Pavlos Fyssas in September 2013, the public prosecutor has labeled GD a criminal organization and all 18 parliamentary deputies of GD are awaiting trial on allegations of murder, attempted murder, aggravated assault, trafficking, kidnapping, money-laundering, possession of weapons and extortion. The fact that the party still has stable support even after the prosecution of 
its members points to the need awareness to be raised on the strong roots of extremism and populism in Greek society.

\section{REFERENCES}

Akrivopoulou, C., Golden Dawn Party Faces Prosecution, Int'l J. Const. L. Blog, Oct. 28,

2013 available at:http://www.iconnectblog.com/2013/10/golden-dawn-party-faces-prosecution

Aksoy, D.

2012 “The flag or the pocketbook: To what are immigrants a threat?", International migration, 50(6): 28-41.

Aradau, C., and R. Van Munster

2009 "Exceptionalism and the 'War on Terror': Criminology Meets International Relations", British Journal of Criminology, 49(5): 686-701.

Baldwin-Edwards, M., and R. Fakiolas

1998 "Greece: the contours of a fragmented policy response", South European Society and Politics, 3(3): 186-204.

Balzacq, T.

2011 Securitization Theory. How security problems emerge and dissolve. Routledge, London.

Bigo, D.

2001 "The Mobius Ribbon of Internal and External Security(ies)" in M. Albert, D. Jacobson and Y. Lapid (Eds) Identities, borders, orders: rethinking international relations theory. University of Minnesota Press, Minneapolis: 91-116.

2002 "Security and immigration:toward a critique of the governmentality of unease", Alternatives, 27(2): 63-92.

2008 "Globalized (in)security:the field and the ban-opticon" in D. Bigo and A. Tsoukala (Eds) Terror, insecurity and liberty: illiberal practices of liberal regimes after 9/11. Routledge, London; 10-48.

Bourbeau, P.

2014 "Moving forward together: Logics of the securitisation process", Millenium: Journal of International Studies, 43(1): 187-206.

Buzan, B., O. Wæver, and J. de Wilde

1998 Security: a new framework for analysis. Lynne-Rienner, Boulder.

Casey, J.P.

2010 “Open borders: absurd chimera or inevitable future policy?”, International Migration, 48(5): 14-62.

Diez, T.

2007 The socio political effects of securitizing free movement: the case of 09/11: full research report. ESRC end of award report, RES-223-25-0055, Swindon; ESRC.

DocTV

2013 "Make their lives hard", [online] 20 December, Available at:http://www.doctv.gr/page.aspx?itemID=SPG5596 (Accessed-on-28/12/2013).

Entman, R.M.

1993 "Framing: towards clarification of a fractured paradigm", Journal of Communication Studies, 43(4): 51-58.

Eurobarometer

1997 Special Report, Racism and Xenophobia. Human rights and Immigration in the European Union, Eb 47.1, December 1997, No. 113.

Faist, - T.

2004 The Migration Security nexus. International migration and security before and after 9/11. Willy Brandt Series of Working Papers in International Migration and Ethnic Relations 4/03, Malmo University.

Gropas, R., and A. Triandafyllidou

2005 "Migration in Greece at a Glance", 29 Athens:ELIAMEP-Hellenic Foundation for European and Foreign Policy. 
Halikiopoulou, D., and S. Vasilopoulou

2013 "The rise of the Golden Dawn", in The Changing Faces of Populism: Systemic Challengers in Europe and the US. H. Giusto, D. Kitching and S. Rizzo (Eds). Foundation for European Progressive Studies, Brussels.

HLHR

2009 Report About the Detention Facilities of Undocumented Migrants in Rodopi and Evros, Available at:www.hlhr.gr/index.php?MDL=pages \&SiteID =352.

HRW

2013 "Unwelcome Guests: Greek Police abuses of migrants in Athens", available at:http://www.refworld.org/docid/51bae3274.html.

Huntington, S.P.

1996 The clash of civilizations and the remaking of world order. Simon \& Schuster, New York.

Huysmans, J.

2000 "The European Union and the securitization of migration", JCMS: Journal of Common Market Studies, 38(5): 751-777.

2006 The Politics of Insecurity. Fear, migration and asylum in the EU. Routledge, London.

2011 "What's in an act? On security speech acts and little security nothings", Security Dialogue, 42(45): 371-383.

Ibrahim, M.

2005 "The Securitization of Migration: A Racial Discourse1”, International migration, 43(5): $163-187$.

Ikenberry, G.J.

1994 "History's Heavy Hand. Institutions and the Politics of the State." Personalwebsite, http:// www.princeton.edu/ gji3/index.html.

IOM

2008 "Migration in Greece: a country profile 2008". International Organization for Migration, October 2008.

Karyotis, G.

2012 "Securitization of migration in Greece:process, motives, and implications", International Political Sociology, 6(4): 390-408.

Karyotis, G., and D. Skleparis

2013 "Qui Bono? The Winners and Losers of Securitising Migration”, Griffith Law Review, 22(3): 683706.

Koronaiou, A., and A. Sakellariou

2013 'Reflections on 'Golden-Dawn', community organizing and nationalist solidarity: helping (only) Greeks", Community Development Journal: 332-338.

Lazaridis, G., and E. Wickens

1999 "US and the 'OTHERS': ethnic minorities in Greece”, Annals of Tourism Research, 26:632-655.

Lazaridis, G.

2011 Security Insecurity and Migration in Europe, Aldershot, Ashgate.

Mahoney, J.

2001 The Legacies of Liberalism: Path Dependence and Political Regimes in Central America. Johns Hopkins University Press, Baltimore.

Massey, D.

2009 "Racial Formation in Theory and Practice: The Case of Mexicans in the United States", Race and Social Problems, 1(1): 12-26.

Mavrodi, G.

2010 "The Other side of 'Fortress-Europe': Policy Transfers in the EU and the Liberalising Effects of EU Membership on Greek Immigrant Policy”, Bielefeld:COMCAD Working Paper \#89.

McDonald, M.

2008 "Securitization and the Construction of Security", European Journal of International Relations, 14 (4): 563-587.

Papageorgiou, I.

2013 "The Europeanization of Immigration and Asylum in Greece (1990-2012)", International Journal of Sociology, 43(3): 72-90. 
Pro Asyl

2012 "Walls of Shame: Accounts from the Inside", available at: http://www.proasyl.de/fileadmin/fm-dam/ Proto Thema q_PUBLIKATIONEN/2012/Evros-Bericht_12_04_10_BHP.pdf.

2013 “Adonis: We must make migrants' lives hard". [online] 10 June, Available at: http://www.protothema.gr/politics/article/?aid=285345 (Accessed-on-15/06/2013).

Skleparis, D.

2015 "(In)securitization and illiberal practices on the fringe of the EU", European Security, doi:10.1080/ 09662839.2015 .1080160 .

Sørensen, N.N.

2012 "Revisiting the migration-development nexus: From social networks and remittances to markets for migration control", International migration, 50(3): 61-76.

Terkessidis, $\mathrm{M}$.

2004 Die Banalität des Rassismus: Migranten zweiter Generation entwickeln eine neue Perspektive, Kultur und soziale Praxis. Transcript, Bielefeld.

UNHCR

2010 "UNHCR says Asylum Situation in Greece is 'a Humanitarian Crisis"”, Available at: www.unhcr.org/4c98a0ac9.html.

Wæver, O.

1995 "Securitization and Desecuritization", On Security. R.D. Lipschultz (Ed.). Columbia University Press, New York: 46-86. 